\title{
ИЗМЕНЕНИЕ СТРАТЕГИИ БЕЗОПАСНОСТИ АВСТРАЛИИ В АЗИАТСКО-ТИХООКЕАНСКОМ РЕГИОНЕ
}

\author{
Ю. И. МАЛЕВИЧ, К. И. ЯРМОШУК \\ Белорусский государственный университет \\ Минск, Республика Беларусь
}

\begin{abstract}
Аннотация. В данном исследовании рассмотрен генезис стратегии безопасности Австралии в Азиатско-Тихоокеанском регионе (АТР). Автор выделяет два этапа в генезисе стратегии безопасности, аргументирует хронологические рамки выделенных этапов, описывает предпосылки изменения стратегии, выделяет три составляющие новой стратегии и дает подробную их характеристику. Новизна данной работы заключается в том, что она является первым комплексным русскоязычным исследованием генезиса стратегии безопасности Австралии в АТР, включающим аргументирование выбора определенной стратегии и условия перехода к новой на основе междисциплинарного анализа преимущественно австралийских источников и историографии. В результате работы автор приходит к выводу, что в генезисе стратегии Австралии в АТР стоит выделить 2 этапа:

1. 2011-2018 гг. - на фоне конкуренции КНР и США в регионе Австралия применяет стратегию балансирования между США (ее главный военнополитический партнер) и КНР (ее главный торгово-экономический партнер);

2. 2018 г. - н.в. - стратегия балансирования претерпела ряд изменений, в результате чего Австралия применяет новую стратегию балансирования. Результаты работы могут быть использованы для дальнейшей разработки данной темы и в более комплексных исследованиях в сфере международной безопасности.
\end{abstract}

Ключевые слова: Азиатско-Тихоокеанский регион; стратегия балансирования; ось средних держав; COVID-19; национальная безопасность; диверсификация экспорта.

Образец цитирования: Малевич Ю. И., Ярмошук К. И. Изменение стратегии безопасности Австралии в Азиатско-Тихоокеанском регионе // Актуальные проблемы международных отношений и глобального развития: сб. науч. ст. Минск, 2021. Вып. 9. С. 242-262. https://doi.org/10.33581/2311-9470-2021-9-242262

Введение. Центральным интересом любого государства является его безопасность. В последние годы самым ярким событием, которое значительно повлияло не только на жизнедеятельность человечества, но и на такие международные процессы, как здравоохранение, туризм, миграция, экономика, политика и, конечно же, геополитика и 
сфера безопасности, стала пандемия COVID-19. Несмотря на то, что пандемия остановила множество международных поездок - геополитические изменения в АТР не останавливались. Премьер-министр Австралии Скотт Моррисон признал тектонические сдвиги в глобальном порядке, когда сказал: «Мы находимся в процессе наиболее серьезной стратегической перестройки со времен Второй мировой войны» [1]. Более того, значимость обстановки в условиях пандемии COVID-19 подчеркивается и в новой оборонной стратегии Австралии 2020 г. «2020 Defence Strategic Update» («Обновление оборонной стратегии» (2020)). В ней отмечается, что «появились и дополнительные факторы, которые будут определять обстановку в Австралии и влиять на оборонное планирование, в частности, экономические и стратегические последствия пандемии COVID-19» ${ }^{1}$. Сейчас мы можем наблюдать изменение стратегии безопасности Австралии в АТР и, что не удивительно, пандемия также наложила свой отпечаток на этот процесс, поэтому тема исследования как никогда актуальна.

Методология исследования. Объект исследования - региональные политические отношения в сфере безопасности. Предмет исследования - стратегия безопасности Австралии в АТР. Целью работы является определение и характеристика генезиса стратегии безопасности Австралии в АТР. Для достижения данной цели были поставлены следующие задачи:

1. Охарактеризовать стратегию балансирования, применяемую Австралией.

2. Выявить основные предпосылки трансфера к новой стратегии.

3. Описать и выделить основные составляющие новой стратегии балансирования.

Для решения этих задач применялись ряд общефилософских (диалектический метод, принцип всесторонности, принцип детерминизма), общенаучных (анализ, синтез) и частнонаучных (историкогенетический, компаративный, историко-ретроспективный) методов.

Историография исследования. Принимая во внимание тему исследования и тот факт, что тема является комплексно неизученной в русскоязычном научном пространстве, данное исследование в основном базируется на австралийских источниках и историографии. Австралийских авторов отличает междисциплинарный подход, взгляд «изнутри», принятие во внимание внутриполитических особенностей

\footnotetext{
${ }^{1} 2020$ Force Structure Plan // Australian Defence Department [Electronic resource]. 2021. URL: https://www1.defence.gov.au/about/publications/2020-force-structure-plan (accessed: 26.05.2021).
} 
и политической традиции, высокая степень детализации и проработанности тем исследований по Австралии, оперирование большим количеством статистических данных. Также стоит отметить тенденцию к прогнозам и составлению пула конкретных предложений для госаппарата по решению определенной проблемы или по улучшению существующего положения вещей.

Результаты исследования. В генезисе стратегии Австралии в АТР стоит выделить 2 этапа:

1. 2011-2018 гг. - на фоне конкуренции КНР и США в регионе Австралия применяет стратегию балансирования между США (главный военно-политический партнер) и КНР (главный торговоэкономический партнер).

2. 2018 г. - н.в. - стратегия балансирования претерпела ряд изменений, в результате чего Австралия применяет новую стратегию балансирования.

Когда США совершили поворот в сторону Азии в 2011 г., расстановка сил в АТР характеризовалась соперничеством двух региональных лидеров - США и КНР. Нельзя было говорить о региональном лидерстве Японии и Ю. Кореи, которые находились в зависимости от США в сфере обеспечения безопасности. Несмотря на впечатляющий экономический рост Индии, наличие ядерного оружия и возросшую внешнеполитическую активность, сохраняющиеся внутренние проблемы (низкий индекс человеческого развития, голод, экологические проблемы, рост населения и уровня безработицы, сравнительно небольшие отчисления в военный сектор) и тот факт, что основное внимание Индия уделяла своему непосредственному региону - ИТР, заявлять о лидерстве Индии в АТР тоже было нельзя [2]. Говоря об Австралии, то она, являясь субрегиональным лидером в ЮТР, не была лидером во всем АТР, т.к. находилась в условиях военнополитической зависимости от США и торгово-экономической - от КНР. Это объясняется следующим.

Австралийская безопасность строится на альянсе с США в рамках соглашения АНЗЮС 1951 г., который оформил стратегический альянс этих двух стран. Более того, в Белых книгах по вопросам безопасности (2009, 2013 и 2016 гг.) отмечается, что Австралия считает, что в обозримом будущем вряд ли появится держава, которая смогла бы оспорить лидерство США, поэтому приверженность Австралии альянсу и не вызывает сомнения. Основными сферами сотрудничества Австралии и США в военно-политическом плане являются борь- 
ба с международным терроризмом, оборона самой Австралии, региональная и международная безопасность, военная модернизация, космическая сфера, ИКТ и кибербезопасность, ОМУ, ПРО и сотрудничество в области миграции.

КНР - с 2013 г. основной торгово-экономический партнер Австралии. В то время была активна риторика о том, что Австралия приветствует дальнейший экономический рост КНР, так как она способствует росту и развитию самой Австралии, а также что Австралия не считает КНР соперницей в регионе. Более того, в Белых книгах по вопросам безопасности говорилось о том, что Австралия отмечает, что рост расходов на оборону КНР является логичным последствием ее стремительного экономического роста и заинтересованности не только в региональных, но и в глобальных вызовах. Китай играет центральную роль в содействии миру и стабильности в Северной Азии и Индо-Тихоокеанском регионе, поэтому в будущем Австралия будет укреплять связи с КНР в области обороны.

В таких условиях, когда США являются главным военнополитическим, а КНР - главным торгово-экономическим партнером Австралии, встает вопрос о том, какую стратегию выбрала Австралия, чтобы получить максимум выгоды для себя. Такой стратегией стала политика балансирования между США и КНР.

Ниже стоит привести пример того, как Австралия успешно применяла стратегию балансирования. Как известно, наряду с такими болезненными точками в отношениях США - КНР, как увеличение военного бюджета КНР, модернизация НОАК, вопрос Тайваня и островов в ЮКМ и защита интеллектуальной собственности, также острым вопросом является соблюдение прав человека в КНР. В этой связи важно отметить особенный подход Австралии к вопросу прав человека. Являясь союзником США, Австралия разделяет те же либеральные ценности. Но Австралия оценивала и комментировала лишь наиболее резонансные события в КНР, например, события на площади Тяньаньмэнь 1989 г. или вооруженное подавление публичных выступлений в Тибете и Синьцзяне. Однако для того, чтобы сохранить высокий уровень дипотношений, Австралия, к примеру, стала первым государством, которое установило диалог с КНР по вопросам прав человека в 1991 г., а в 2001 г. отказалась от соавторства резолюции $\mathrm{OOH}$ по соблюдению прав человека в КНР, таким образом сохранив благоприятные рабочие отношения для продвижения своих экономических интересов в отношениях с КНР [3]. 
Хотя согласие Австралии при Дж. Гиллард разместить американский контингент войск на территории Австралии вызвало недовольство и волну критики со стороны КНР, на экономические отношения между странами это никак не повлияло, и в 2013 г. Китай стал главным торгово-экономическим партнером Австралии. В 2014 г. Тони Эббот и Си Цзиньпин подписали договор о создании Зоны свободной торговли (ЗСТ) между двумя государствами. Народный банк КНР и Резервный банк Австралии подписали меморандум о расчетах в юанях. Соглашение о ЗСТ Австралии и КНР стало значимым шагом в укреплении экономических отношений обеих стран. Еще одним интересным примером балансирования можно назвать тот факт, что в 2015 г. Китай арендовал в Австралии порт Дарвин на 99 лет. Примечательно, что как раз в Дарвине располагается батальон Корпуса морской пехоты США [3].

Однако на современном этапе наблюдается изменение стратегии балансирования Австралии. Эту стратегию можно назвать «новой стратегией балансирования».

Можно сказать, что изменение стратегии Австралии заключается в следующем: оставаясь приверженной политике балансирования между США и Китаем, она переходит к большей самостоятельности, что проявляется в стремлении:

1. Выстроить ось средних держав, которая была бы противовесом и некоторым сдерживающим фактором США и КНР.

2. Отойти от полной зависимости от США и перейти к больщей самостоятельности в вопросе обеспечения собственной безопасности.

3. Снизить зависимость в экономическом плане от КНР и диверсифицировать экспорт.

После отказа Huawei предоставить 5G технологии в Австралии в 2018 г., актуализировалась риторика о необходимости изменения политики балансирования Австралии и о переходе к «новой стратегии балансирования».

Предпосылки изменения стратегии:

1. Китай становится более агрессивным. Недавно, после призыва премьер-министра Скотта Моррисона провести независимое международное расследование происхождения вспышки COVID-19, Китай приостановил импорт говядины из четырех австралийских скотобоен и ввел ужасающий 80-процентный тариф на австралийский ячмень. Хотя австралийские официальные лица это отрицают, пред- 
ставители промышленности, журналисты и экономисты истолковали эти события как попытки Пекина наказать Австралию за ее политические ошибки. То есть КНР сейчас - это развивающаяся сверхдержава, которая с каждым днем становится все более требовательной: остро реагирует на претензии и наказывает тех, кто их высказывает [4]. После того, как Китай ввел тарифы на ячмень, отраслевые группы Австралии призвали прекратить критику политики Пекина и «перезагрузить» китайско-австралийские отношения. Однако это не является выходом из положения. Что Австралии нужно, так это диверсифицировать экспорт и укреплять связи с ее традиционными друзьями. Это исходит из признания того, что в долгосрочной перспективе секторы, чрезмерно зависящие от Китая, представляют собой стратегическую уязвимость для Австралии. Поэтому Австралии стоит предпринять шаги, чтобы отлучить КНР от такой критически важной инфраструктуры, как электросети, айти-активы, сельскохозяйственные угодья, порты, медицинские учреждения, а также сократить исследовательские связи с университетами, которые помогают расширить возможности Китая [5].

2. Подход администрации США «Америка прежде всего». США, которые все больше обращают внимание на свои внутренние дела, а не на партнерства, все менее обнадеживают [1]. Пандемия подтверждает суровую реальность того, что национальное государство является основным источником безопасности. Союз Австралии с США неоценим, и его необходимо поддерживать, но Австралия не может вверять свою безопасность Вашингтону полностью [5]. Поэтому в Австралии задались вопросом, правильны ли приоритеты оборонной политики государства и есть ли немедленная необходимость в создании более сильного и самостоятельного военного потенциала [6].

Теперь стоит глубже рассмотреть элементы новой стратегии балансирования:

\section{1. Ось средних держав.}

Говоря о нововведениях в традиционной стратегии балансирования, рассмотрим стремление Австралии после пандемии выстроить своеобразную «ось средних держав» [7].

В новой оборонной стратегии Австралии 2020 г. отмечается, что крупные державы стали более настойчиво продвигать свои стратегические интересы и стремиться оказывать влияние в регионе, включая старания Китая усилить влияние в ИТР. 
Австралия обеспокоена возможностью таких действий, как создание военных баз, которые могут подорвать стабильность в регионе и заявляет, что очень важно, чтобы страны отстаивали свои интересы на основе взаимного уважения и поддержки стабильности, процветания и безопасности» ${ }^{2}$. А ось средних держав будет как раз-таки направлена на более глубокое двустороннее и многостороннее сотрудничество с существующими партнерами, а также на выстраивание многоуровневых взаимодействий с новыми партнерами в качестве защиты от держав, которые будут стремиться подорвать установленные региональные правила, основанные на международном праве и безопасности.

Ось средних держав плотно свяжет государства в клубок взаимодействий в сфере торговли, безопасности, обмена разведданными, культурного обмена и военного сотрудничества. Этот клубок также должен стать центром с достаточным совокупным стратегическим, экономическим весом и весом в сфере безопасности, чтобы уравновесить двух лидеров в АТР - США и Китай [7]. Это не означает, что Австралия должна разрывать или ослаблять двусторонние отношения, которые у нее есть с США или Китаем, но ось средних держав даст ей больше рычагов давления на эти крупные страны в преследовании своих как экономических интересов, так и интересов в сфере безопасности.

Несмотря на то, что Австралия двигается в сторону большей самостоятельности, вряд ли в обозримом будущем она сможет полностью отойти от традиционного балансирования. Хотя и существует дискурс о диверсификации экономических связей, Китай все еще остается первым торгово-экономическим партнером Австралии.

Если обратиться к статистке, три четверти (75,3\%) австралийского экспорта в 2020 г. были поставлены 15 торговым партнерам. Три первых - это Китай, Япония, США. При этом, показатели Китая - это 90,6 млрд долларов США (43\% от общего объема австралийского экспорта). Для сравнения цифры Японии, которая занимает второе место, - это 19 млрд долларов США (9\%).

Таким образом, разрыв между первым торгово-экономическим партнером Австралии (Китаем) и вторым (Японией) огромен - целых 34\%. Для сравнения третий партнер - США - отстает от Японии

\footnotetext{
2020 Defence Strategic Update // Australian Defence Department [Electronic resource]. 2021. URL: https://www1.defence.gov.au/about/publications/2020-defence-strategic-update. (accessed: 26.05.2021).
} 
лишь на 2,8\% (цифры США - 13,1 млрд долларов (6,2\% австралийского экспорта) ${ }^{3}$. Т.е. отрыв Китая от всех остальных торговоэкономических партнеров Австралии просто колоссален.

В свою очередь не вызывает сомнения тот факт, что Австралия останется привержена военно-политическому альянсу с США. Это подтверждается риторикой в отношении США в новой оборонной стратегии Австралии 2020 г.: «Австралия - верный и активный союзник Соединенных Штатов, которые продолжают обеспечивать безопасность и стабильность ИТР. Мы продолжим работать с Соединенными Штатами над укреплением сотрудничества в области обороны в нашем стратегическом регионе, чтобы противостоять вызовам безопасности и вырабатывать общие подходы к обеспечению стабильности в регионе. Обмен разведданными, а также технологическое и промышленное сотрудничество между Австралией и США имеют решающее значение для национальной безопасности Австралии» ${ }^{4}$.

Таким образом, выстраивание «оси» является шагом Австралии не только к приобретению больших рычагов давления на две сверхдержавы - лидеров в регионе, но и к большей самостоятельности в АТР и приобретению статуса лидера среди средних держав региона.

Для выстраивания такой оси Австралия должна:

1. Удвоить свою вовлеченность и поддержку таких многосторонних форумов, как АСЕАН, АТЭС, ФТО (Форум Тихоокеанских островов) и ВАС (Восточноазиатский саммит).

2. Усилить взаимодействие с ее партнерами - средними державами, включая такие страны, как Япония, Южная Корея, Сингапур, Индонезия, Вьетнам, Индия и другими партнерами, такими как Франция и Великобритания, которые имеют интересы в АТР [7].

3. Заключить ряд многосторонних договоренностей с разными партнерами по различным вопросам - по военному сотрудничеству, безопасности, разведке, экономике. По форме реализации они могут представлять собой новую серию трех- и четырехсторонних соглашений, которые Австралия может комбинировать и сочетать на основе общих интересов участников. К примеру, четырехстороннее сотрудничество Австралии, Индии, Японии и Индонезии, которые проводят

\footnotetext{
${ }^{3}$ Workman D. Australia's Top Trading Partners [Electronic resource] / D. Workman // World's Top Exports. URL: https://www.worldstopexports.com/australias-top-import-partners. (accessed: 23.04.2021).

${ }^{4} 2020$ Defence Strategic Update // Australian Defence Department [Electronic resource]. 2021. URL: https://www1.defence.gov.au/about/publications/2020-defence-strategic-update. (accessed: 26.05.2021).
} 
совместные учения по ликвидации последствий стихийных бедствий, или треугольник Австралии, Вьетнама и Японии по борьбе с пиратством и контрабандой. Франщия, Великобритания и Австралия могли бы работать вместе над реализацией программ развития для тихоокеанских островных государств или над планом развертывания вакцинации против COVID-19 в развивающихся странах региона [7].

Отдельно здесь стоит выделить взаимоотношения с ключевыми островными государствами в ЮТР, которые являются традиционной сферой влияния Австралии и где она борется за лидерство с активизировавшимся в условиях пандемии Китаем. Чтобы минимизировать влияние КНР в регионе, Австралия должна быть главным поставщиком безопасности в ЮТР. Для этого Австралия могла бы формализовать более глубокие отношения в области обороны и безопасности с ключевыми островными странами ЮТР, а также в условиях пандемии предложить договоры, которые обеспечили бы значительное улучшение возможностей островных государств в области здоровья и безопасности населения [5].

Стоит отметить, что вышеперечисленные форматы не должны быть ни за, ни против США или Китая. По необходимости многие форматы должны включать их, т.к. будучи взаимосвязаны через многостороннюю кооперацию со многими партнерами в регионе, им будет сложно подорвать сложившуюся архитектуру и правила [6].

\section{2. Большее участие Австралии в обеспечении безопасности.}

В новой оборонной стратегии Австралии 2020 г. содержится следующий тезис: «Только ядерный и конвенциальный потенциал Соединенных Штатов может обеспечить эффективное сдерживание потенциальных ядерных угроз Австралии. Но правительство намерено, чтобы Австралия взяла на себя большую ответственность за собственную безопасность. Поэтому очень важно развивать собственные военные возможности» 5 .

Более того, в стратегии отмечается, что, учитывая ограниченную ресурсную базу Австралии, она должна наращивать военные возможности собственными темпами, не стремясь соответствовать крупным державам. Это включает в себя развитие возможностей удерживать силы и инфраструктуру противника вдали от Австралии, например, развивая ударное оружие большой дальности и кибер-возможности. К

\footnotetext{
52020 Defence Strategic Update // Australian Defence Department [Electronic resource]. 2021. URL: https://www1.defence.gov.au/about/publications/2020-defence-strategic-update. (accessed: 26.05.2021).
} 
тому же в соответствии с The 2020 Force Structure Plan (План структуры вооруженных сил 2020) правительством будет выделено финансирование в течение десятилетия (до 2029-2030 гг.) в размере около 270 млрд долларов в оборонный потенциал 6 .

Правительство решило, что оборонное планирование будет сосредоточено на ближайшем к Австралии регионе, который является для нее ключевым: от северо-востока Индийского океана, через море и материковую часть Юго-Восточной Азии до Папуа-Новой Гвинеи и юго-западной части Тихого океана (это так называемый «стратегический регион»).

Выбор региона не удивителен, т.к. он является зоной самого прямого стратегического интереса Австралии. В его рамках Австралия должна иметь возможность наращивать свои возможности и оказывать влияние в поддержку общих интересов региональной безопасности и торговли.

Стоит поподробнее рассмотреть планы австралийского правительства по развитию военных возможностей с тем, чтобы приобрести большую самостоятельность в обеспечении собственной безопасности. В Плане структуры вооруженных сил 2020 г. (The 2020 Force Structure Plan) отражаются три новые стратегические оборонные цели, определяемые правительством: 1. формирование стратегической среды вокруг Австралии; 2. сдерживание действий против интересов Австралии; и при необходимости 3. развитие возможности нанести ответ, применив убедительную военную силу.

Общий объем финансирования военной сферы в размере 575 млрд долларов на следующее десятилетие включает около 270 млрд долларов инвестиций в военные возможности (для сравнения во времена Белой книги по вопросам обороны Австралии 2016 г. на эти цели выделялось195 млрд долларов) ${ }^{7}$.

Усилия направлены на пять операционных областей: 1. Информация и кибер-сфера, 2. Морское пространство, 3. Воздушное пространство, 4. Космическое пространство и 5. Наземное пространство.Если проанализировать, то эти 5 направлений можно категоризировать по степени самостоятельности Австралии. Хотя в космической сфере Австралия все также сильно зависит от США, в сфере

\footnotetext{
${ }^{6} 2020$ Defence Strategic Update // Australian Defence Department [Electronic resource]. 2021. URL: https://www1.defence.gov.au/about/publications/2020-defence-strategic-update. (accessed: 26.05.2021).

${ }^{7} 2020$ Force Structure Plan // Australian Defence Department [Electronic resource]. 2021. URL: https://www1.defence.gov.au/about/publications/2020-force-structure-plan (accessed: 26.05.2021).
} 
ИКТ и кибернетики Австралия твердо стоит на ногах. В таких классических военных сферах, как воздух, суша и море Австралия продолжает кооперироваться с США, однако степень Австралийского участия заметно возрастает, особенно в сфере финансирования и инвестирования в новые военные технологии. Такой расклад можно проследить и по тому, как распределены средства для инвестирования в разные военные сферы. В самую зависимую от США сферу (космос) Австралия планирует вложить лишь 7 млрд долларов, а в кибер- и ИКТ сфере, где она пионер, в 2 раза больше - 15 млрд долл. А сферы приоритетного финансирования в передовые технологии морская, воздушная, наземная - примерно равновесны: это 75, 65 и 55 млрд долл. соответственно.

\section{Космическая сфера}

Планируются инвестиции в космический потенциал в размере около 7 млрд долларов в течение следующего десятилетия, включая инвестиции в спутники, контролируемые государством, которые обеспечат гарантированный доступ к ним в случае необходимости 8

Это самая маленькая статья финансирования из всех пяти оборонных сфер, что неудивительно, т.к. Австралия продолжает полагаться на США в космической сфере. Основные возможности спутниковой связи для военных контингентов Австралии будут попрежнему предоставляться через доступ к Глобальной системе «Wideband» под управлением США, которая обеспечивает широкополосную связь для стационарных и крупных мобильных платформ Австралии 9 . Также Австралия продолжит пользоваться возможностями американского радара «С-Band» и высокотехнологичного космического телескопа, направленных в Австралию еще в 2012 г. для того, чтобы отслеживать передвижения космического мусора и других космических объектов, которые могут нанести вред космическим системам безопасности ${ }^{10}$.

\section{Сфера ИКТ и кибернетики}

Стратегия правительства на ближайшее десятилетие включает дальнейшее укрепление разведывательных и кибер-возможностей

\footnotetext{
${ }^{8} 2020$ Force Structure Plan // Australian Defence Department [Electronic resource]. 2021. URL: https://www1.defence.gov.au/about/publications/2020-force-structure-plan (accessed: 26.05.2021).

${ }^{9}$ Defence White Paper 2009 // Australian Defence Department [Electronic resource]. 2009. URL: http://www.defence.gov.au/whitepaper/2009/docs/defence_white_paper_2009.pdf (accessed: 25.06.2021).

${ }^{10}$ Defence White Paper 2013 // Australian Defence Department [Electronic resource]. 2013. URL: http://www.defence.gov.au/whitepaper/2013/docs/WP_2013_web.pdf. (accessed: 26.06.2021).
} 
Австралии, которые имеют решающее значение для выявления и реагирования на иностранные угрозы, нацеленные на интересы Австралии $^{2}$. Не удивительно, что правительство уделяет много внимания вопросам кибербезопасности. В новой оборонной стратегии Австралии 2020 г. отмечается, что «расширение кибервозможностей и готовность некоторых стран и негосударственных субъектов злонамеренно использовать киберпространство еще больше усложняют «окружающую среду» Австралии. Кибератаки могут поставить под угрозу военные операции, приводить к дезинформации и дестабилизирующему вмешательству в экономику, политические и социальные системы и инфраструктуру» ${ }^{11}$. Если рассмотреть глубже, кибербезопасность как никогда важна для экономического процветания и национальной безопасности Австралии. Для примера работа примерно 65\% австралийских предприятий была подорвана в результате взлома системы безопасности в прошлом году, причем половина из них обошлась в сумму от 1 до 4,9 млн долларов [8].

Таким образом планируются инвестиции в программы интеграции, совместные системы командования, управления и связи, операции по радиоэлектронной борьбе и оборонительные операции в киберпространстве посредством интеграции с разведкой. Эти инвестиции будут дополнены созданием новых средств контрразведки, включая инфраструктуру и учебное оборудование. Сумма этих инвестиций в усиление возможностей информационных и киберпространств составит около 15 млрд долларов в течение следующего десятилетия.

\section{Морские, воздушные, наземные силы}

Морские владения имеют особое значение для Австралии, островного государства, окруженного одной из крупнейших в мире исключительных экономических зон, богатых ресурсами, через которые проходит большая часть международной торговли.

План структуры вооруженных сил на 2020 год предусматривает общие запланированные вложения примерно в 75 млрд долларов в течение следующего десятилетия в укрепление морского потенциала Австралии.

Эти расширенные морские силы обеспечат более широкие возможности для борьбы с подводными лодками, будут способствовать

\footnotetext{
112020 Defence Strategic Update // Australian Defence Department [Electronic resource]. 2021. URL: https://www1.defence.gov.au/about/publications/2020-defence-strategic-update. (accessed: 26.05.2021).
} 
операциям по обеспечению безопасности границ, морского патрулирования и разведки и др. ${ }^{12}$

Воздушная сфера имеет решающее значение для ситуационной осведомленности во время операций в мирное время и быстрого реагирования во время бедствий или конфликтов. В регионе страны повсеместно приобретают передовой авиационный потенциал, включая боевые самолеты пятого поколения и высокоскоростное оружие большой дальности. Государственные инвестиции в ВВС составят около 65 млрд долларов в течение следующего десятилетия. Усовершенствованные системы вооружения с большей дальностью и большим сроком службы дадут обороне возможность сдерживать или отражать атаки как можно дальше от Австралии. В планах, чтобы новые и существующие самолеты также сочетались с дистанционно пилотируемыми и автономными системами.

Чтобы обеспечить сохранение в Австралии эффективных средств воздушной разведки, наблюдения и радиоэлектронной борьбы, правительство инвестирует средства в поддержку и модернизацию самолета радиоэлектронной атаки EA-18G Growler и оперативной радиолокационной сети Jindalee (Джиндали) для обеспечения наблюдения за восточными подходами Австралии на обширных территориях. Оперативная радиолокационная сеть Джиндали, основанная на ведущей в мире австралийской технологии, в настоящее время обеспечивает всестороннее наблюдение за северными и западными подходами Австралии и является жизненно важным компонентом сети стратегического наблюдения Австралии ${ }^{13}$.

Министерство обороны также введет в эксплуатацию дистанционно пилотируемую авиационную систему MQ-9B Sky Guardian и caмолет радиоэлектронной борьбы MC-55A Peregrine. Правительство будет поддерживать постоянные инвестиции в обслуживание и модернизацию самолета средней мобильности C-130J Hercules (для средних грузов), самолета тяжелой мобильности Boeing C-17A Globemaster III (для тяжелых грузов), многоцелевого транспортного

\footnotetext{
${ }^{12} 2020$ Force Structure Plan // Australian Defence Department [Electronic resource]. 2021. URL: https://www1.defence.gov.au/about/publications/2020-force-structure-plan (accessed: 26.05.2021).

132020 Defence Strategic Update // Australian Defence Department [Electronic resource]. 2021. URL: https://www1.defence.gov.au/about/publications/2020-defence-strategic-update. (accessed: 26.05.2021).
} 
самолета-заправщика КC-30A и самолета легкой мобильности C-27J Spartan (для легких грузов) ${ }^{14}$.

На протяжении всей своей истории сухопутные силы Австралии выполняли широкий круг задач - от гуманитарной помощи и помощи при стихийных бедствиях до поддержания мира и, в конечном итоге, боевых операций. Чтобы вооружить сухопутные войска для решения этих задач в будущем, планируются новые инвестиции в ударное вооружение, гидроциклы, вертолеты, логистику, а также новые автономные систему и робототехнику. Эти возможности повысят боевую мощь сухопутных войск и предоставят правительству больше возможностей для развертывания ПВО в более конкурентной среде, с которой сейчас сталкивается Австралия и, как ожидается, столкнется с ней в будущем.

Изложенные выше программы также повысят способность Австралии поддерживать страну во время внутреннего кризиса и оказывать в регионе гуманитарную помощь или участвовать в операциях по стабилизации. Общий объем инвестиций в наземные силы составит около 55 млрд долларов в течение следующего десятилетия.

\section{3. Диверсификация экспорта}

Характеризуя экономику Австралии, стоит сказать, что она экспортоориентированная. В 2019 г. ВТО поставила Австралию на 21-е место в списке крупнейших экспортеров в мире с 1,4\% от общего объема экспорта и на 24-е место среди импортеров, на которые приходилось 1,2\% мирового импорта [9]. То есть Австралия очень зависит от экспорта своих товаров и услуг. Более того, экономика Австралии очень узко сконцентрированная: $82 \%$ товарного экспорта в 2019 г. приходились на Индо-Тихоокеанские рынки, при этом на Китай приходилось около одной трети от общего объема. Ресурсы составляют примерно половину всего экспорта, при этом преобладают три товара - уголь, железная руда и природный газ. На втором месте с $22 \%$ - это услуги, в основном это образовательные услуги и туризм. Недавний анализ, проведенный Центром США - Азия города Перт (Perth USAsia Center), показывает, что половина из 30 ведущих экспортных отраслей Австралии приходится на один доминирующий рынок - Китай [10]. Неудивительно, что Китай является первым торгово-экономическим партнером Австралии.

\footnotetext{
${ }^{14} 2020$ Force Structure Plan // Australian Defence Department [Electronic resource]. 2021. URL:
} https://www1.defence.gov.au/about/publications/2020-force-structure-plan (accessed: 26.05.2021). 
Примечательно, что на фоне пандемии COVID-19 у Австралии и КНР образовался торговый конфликт. Китай ввел санкции в отношении экспорта Австралийского ячменя, говядины, образовательных услуг и туризма, что являлось явным ответом на позицию Австралии по независимому международному расследованию возникновения COVID-19.

Предполагается, что Австралия еще столкнется с подобными экономическими шоками, поэтому Межпартийный парламентский комитет Австралии рекомендовал стране диверсифицировать свой эксnорт и избавиться от зависимости от Китая, чтобы подобные «шоки» не были столь разрушительными [11].

На современном этапе Вьетнам, Индонезия и Индия являются для Австралии привлекательными партнерами в деле диверсификации своих экономических отношений.

Вьетнам считается примером одной из историй успеха во время пандемии COVID-19 и представляет собой идеального экономического партнера для Австралии: во Вьетнаме стабильная бизнес-среда и быстрорастущая экономика, движимая молодой демографией и быстрой урбанизацией, и индустриализацией. В настоящее время на Вьетнам приходится всего 1,7\% двусторонней торговли Австралии, что указывает на наличие значительных возможностей для роста [10]. Хотя Китай традиционно превосходит всех в качестве основного направления экспорта хлопка из Австралии с 2010 г., Вьетнамский рынок хорошо зарекомендовал себя в качестве альтернативного для австралийского экспорта в течение последних шести лет [9]. Стоит повториться, что Вьетнам был одной из немногих стран, где в 2020 г. наблюдался рост экономики. Его текстильная и швейная промышленность пострадали от пандемии меньше, чем в других странах. Также Вьетнам смог сохранить позицию второго крупнейшего партнера Австралии по экспорту хлопка после Китая в 2020 г. [9]. Это означает, что Австралия имеет хорошие возможности для увеличения доли импорта во Вьетнам.

Говоря об Индонезии, стоит отметить, что это крупнейшая экономика Юго-Восточной Азии и 16-я по величине экономика в мире. По некоторым оценкам, к 2030 г. Индонезия станет пятой экономикой мира. С населением в 264 млн человек Индонезия предоставляет значительные возможности для австралийских предприятий. Страна также является 14-м крупнейшим торговым партнером Австралии. 
Вышеперечисленное и предопределяет интерес Австралии к усилению торгово-экономических отношений с этой страной.

Примечательным шагом стало подписание Соглашения о всеобъемлющем экономическом партнерстве между Индонезией и Австралией (The Indonesia-Australia Comprehensive Economic Partnership Agreement (IA-CEРА), которое вступило в силу 5 июля 2020 г. В связи с этим стоит выделить ключевые преимущества Соглашения для Австралии в торговле товарами: свыше 99\% экспорта австралийских товаров в Индонезию будет осуществляться беспошлинно или по значительно улучшенным преференциальным соглашениям. Индонезия также гарантирует автоматическую выдачу разрешений на импорт ключевых продуктов, таких как живой скот, замороженная говядина, баранина, кормовые зерна, сталь, цитрусовые, морковь и картофель. Также соглашение предоставляет выгодные условия по линии торговли услугами и особенно туризма (преимущественно в сфере образования). Предполагается, что Соглашение стало стартовой площадкой для дальнейшего развития продуктивных и взаимовыгодных партнерских отношений.

В отчете Объединенного постоянного комитета Австралии по росту торговли и инвестиций (Joint Standing Committee on Trade and Investment Growth) говорится, что сокращение зависимости от Китая в структуре экспорта Австралии - это очень сложная задача и что «не считая Индии, нет единого национального рынка, который смог бы запросить Австралийский экспорт в том размере товаров и услуг, что Австралии надо продавать» [11]. Поэтому стоит обратить отдельное внимание на Индию в этом вопросе, т.к. в экономическом плане последние несколько лет отношения между Индией и Австралией активно развиваются. Индия была 8-м по величине торговым партнером Австралии и 3-м по величине рынком экспорта услуг в 2019-2020 гг. В 2019-2020 гг. двусторонняя торговля товарами и услугами составила 26,2 млрд долларов, а объем двусторонних инвестиций в 2019 г. составил 36,7 млрд долларов, что является достаточно неплохими цифрами [12].

18 декабря 2020 г. Индия издала Отчет об экономической стратегии в отношении Австралии (Australia Economic Strategy), который является единственным стратегическим отчетом, когда-либо подготовленным правительством Индии для какой-либо конкретной страны. Более того, он является ответом на такой же отчет по экономической стратегии Австралии в отношении Индии до 2035 г., выпу- 
щенный в 2018 г. Стратегия ставит перед Индией цель стать одним из трех крупнейших экспортных рынков Австралии, сделать Индию третьим по величине направлением в Азии для австралийских инвестиций (в размере 100 млрд долларов к 2035 г.) и выстроить сбалансированные взаимовыгодные торговые отношения между обеими странами [13].

2020 год был по-настоящему продуктивным для АвстралийскоИндийских торгово-экономических отношений. Торговые и инвестиционные отношения между Австралией и Индией получили серьезный импульс после запуска Австралийско-индийской деловой биржи (the Australia India Business Exchange). Биржа предоставляет компаниям в обеих странах понимание рынков друг друга, а также связи для развития коммерческих партнерств, которые помогут создать рабочие места и возможности для бизнеса в Австралии и Индии. Биржа также поможет австралийским поставщикам продуктов питания, напитков и потребительских товаров премиум-класса получить доступ к каналам электронной коммерции Индии [12].

Не менее значимым событием стал исторический виртуальный саммит между премьер - министрами Австралии и Индии в июне 2020 г., который привел к повышению уровня двусторонних отношений и установил их в статусе Всеобъемлющего стратегического партнерства [13]. Премьер - министр С. Моррисон на саммите заявил: «Я думаю, что Всеобъемлющее стратегическое партнерство, которое мы формируем сегодня, перейдя на совершенно новый уровень отношений, продолжит укреплять доверие, потому что мы хотим, чтобы коммерческие и торговые отношения строились на доверии» [14]. Судя по тому, как быстро и активно по многим направлениям развивается двустороннее сотрудничество между Индией и Австралией, вполне логично ожидать, что следующей страной, с кем Австралия подпишет договор о создании ЗСТ, будет Индия [15].

Выводы. Таким образом, в генезисе стратегии Австралии в АТР стоит выделить 2 этапа:

1. 2011 - 2018 гг. - на фоне конкуренции КНР и США в регионе Австралия применяет стратегию балансирования между США (главный военно-политический партнер) и КНР (главный торговоэкономический партнер).

2. 2018 г. - н.в. - стратегия балансирования претерпела ряд изменений, в результате чего Австралия применяет новую стратегию балансирования. 
Предпосылки изменения стратегии:

1. Агрессивность КНР (приостановка и введение тарифов на основные экспортные позиции Австралии),

2. Подход администрации США «Америка прежде всего» (обращение внимания США преимущественно на свои внутренние дела, а не на партнерства).

Изменение стратегии Австралии заключается в следующем: оставаясь приверженной политике балансирования между США и Китаем она переходит к большей самостоятельности, что проявляется в стремлении:

1. Выстроить ось средних держав, которая была бы противовесом и некоторым сдерживающим фактором США и КНР. (Выстраивание клубка двусторонних и многосторонних партнерств средних держав с достаточным совокупным стратегическим, экономическим весом и весом в сфере безопасности, чтобы уравновесить две сверхдержавы в регионе - США и Китай).

2. Отойти от полной зависимости от США и перейти к большей самостоятельности в вопросе обеспечения собственной безопасности. (Австралия очень активна в сфере ИКТ и кибернетики, а в таких классических военных сферах, как воздух, суша и море хотя Австралия продолжает кооперироваться с США в рамках военного альянса, однако степень Австралийского участия заметно возрастает через мощное финансирование и инвестирование в новые военные технологии).

3. Снизить зависимость в экономическом плане от КНР и диверсифицировать экспорт (как приоритетные альтернативные рынки Австралия рассматривает Вьетнам, Индонезию и Индию).

\section{Библиографические ссылки}

1. Huong Le Thu. The COVID-19 Pandemic and Geopolitics in Southeast Asia [Electronic resource] / Huong Le Thu// Australian Strategic Policy Institute. URL: https://www.aspi.org.au/ opinion/covid-19-pandemic-and-geopolitics-southeast-asia. (accessed: 22.05.2021).

2. Lowther A. The Asia-Pacific Century: Challenges and Opportunities / A. Lowther // Air Force Research Institute [Electronic resource]. Alabama, 2013. URL: https://media.defense.gov/2017/ Apr/07/2001728463/-1/-1/0/B_0132_LOWTHER_ASIA_PACIFIC1.PDF. (accessed: 04.05.2021).

3. Белей С. И. Фактор Китая в политике Австралии в Азиатско-Тихоокеанском регионе/С. И. Белей// Журнал международного права и международных отношений. 2014. № 1. С. 33-37.

4. Xiuzhong $X u, V$. Why Australia must not bow to China but seek wider trade options [Electronic resource] / V. Xiuzhong Xu // Australian Strategic Policy Institute. URL: https://www.aspi. org.au/opinion/why-australia-must-not-bow-china-seek-wider-trade-options (accessed: 23.04.2021). 5. Jennings $P$. National security strategy can help us build key alliances to counter China [Electronic resource] / P. Jennings// Australian Strategic Policy Institute. URL: https://www. 
aspi.org.au/opinion/national-security-strategy-can-help-us-build-key-alliances-counter-china (accessed: 23.04.2021).

6. Jennings $P$. We need to reduce our dependence on China, and have the courage to call it out when required [Electronic resource] / P. Jennings// Australian Strategic Policy Institute. URL: https://www.aspi.org.au/opinion/we-need-reduce-our-dependence-china-and-have-courage-call-itout-when-required (accessed: 25.03.2021).

7. Khalil $P$. The future of Australian foreign policy: beyond the major powers, towards a 'fulcrum' of middle powers [Electronic resource] // After Covid-19: Voices from federal parliament (Volume 3). URL: https://s3-ap-southeast-2.amazonaws.com/ad-aspi/2020-12/After\%20Covid19\%20Volume\%203_1.pdf?YAvLkXatwCsGNLpd82TXp.B9SGqkci3n (accessed: 15.04.2021).

8. Bachhawat A., Cave, D. Critical technologies and the Indo-Pacific [Electronic resource] / A. Bachhawat, D. Cave // Australian Strategic Policy Institute. URL: https://s3-ap-southeast2.amazonaws.com/ad-aspi/2020-10/Critical\%20technologies_0.pdf?XWYJ1CHFPRHowYQcge YRPD0LvmEEEGD7- (accessed: 15.04.2021).

9. Hull G. Too Many Eggs in the Dragon's Basket? Part Two: Diversifying Australia's Export Base [Electronic resource] // Future Directions International. URL: https://www.futuredirections. org.au/publication/too-many-eggs-in-the-dragons-basket-part-two-diversifying-australias-exportbase/ (accessed: 15.04.2021).

10. Wilson J. Trade Diversification is Essential for Australia's Recovery [Electronic resource] / J. Wilson// Australian Institute of International Affairs. URL: https://www.internationalaffairs.org.au/ australianoutlook/trade-diversification-essential-for-australias-recovery/ (accessed: 15.04.2021).

11. Morrison K. Australia urged to diversify exports away from China [Electronic resource] / K. Morrison// Argus Media Group. URL: https://www.argusmedia.com/en/news/2197091-australiaurged-to-diversify-exports-away-from-china (accessed: 15.04.2021).

12. Dipanjan $R$. India-Australia trade $\&$ investment ties to get major boost with Australia India Business Exchange launch [Electronic resource] / R. Dipanjan // The Economic Times. URL: https://economictimes.indiatimes.com/news/international/world-news/india-australia-trade-invest ment-ties-to-get-major-boost-with-australia-india-business-exchange-launch/articleshow/81943822. cms?utm_source=contentofinterest\&utm_medium $=$ text\&utm_campaign $=$ cppst $\quad$ (accessed: 15.08.2021).

13. Jha Bhaskar N. Australia and India Economic Relations: The Stars Have Aligned [Electronic resource] / N. Jha Bhaskar // The Diplomat. URL: https://thediplomat.com/2020/12/australia-andindia-economic-relations-the-stars-have-aligned/ (accessed: 15.08.2021).

14. India-Australia trade agreement gathering momentum under Morrison: Report // bilaterals.org [Electronic resource]. 2021. URL: https://www.bilaterals.org/?india-australia-trade-agreement \&lang=en (accessed: 26.08.2021).

15. India - our next free trade agreement? // Business Australia [Electronic resource]. 2020. URL: https://www.businessaustralia.com/how-we-help/grow-your-business/preparing-to-export/india-ournext-free-trade-agreement (accessed: 24.08.2021).

Дата поступления статьи: 30.09.2020.

Авторы: Малевич Юлианна Игоревна - доктор политических наук, профессор, профессор кафедры международных отношений БГУ; e-mail: myjil1352@gmail.com.

Ярмошук Карина Игоревна - аспирант кафедры международных отношений БГУ; e-mail: karinayarmoshuk@gmail.com 


\title{
CHANGE IN AUSTRALIA'S SECURITY STRATEGY IN THE ASIAN-PACIFIC REGION
}

\author{
Y. I. MALEVICH, K. I. YARMOSHUK. \\ Belarusian State University, Minsk, Republic of Belarus
}

\begin{abstract}
This study examines the genesis of Australia's security strategy in the Asia-Pacific region (APR). The author identifies 2 stages in the genesis of the security strategy, argues the chronology of the identified stages, describes the prerequisites for changing the strategy, identifies three components of the new strategy and gives a detailed description of them. The novelty of this work is that this analysis is the first comprehensive Russian-language study of the genesis of Australia's security strategy in the Asia-Pacific region, including argumentation for the choice of a certain strategy and the conditions for the transition to a new one on the basis of an interdisciplinary analysis of predominantly Australian sources and historiography. As a result of the study, the author comes to the conclusion that in the genesis of Australia's strategy in the Asia-Pacific region it is worth highlighting 2 stages:

1. 2011-2018 - considering the competition between the PRC and the United States in the region, Australia is applying a strategy of balancing between the United States (its main military-political partner) and the PRC (its main trade and economic partner).

2. 2018 - present - the balancing strategy has undergone a number of changes, as a result of which Australia is adopting a new balancing strategy. The results of the work can be used for further development of this topic and in more comprehensive studies in the field of international security.
\end{abstract}

Keywords: Asia-Pacific region; balancing strategy; middle powers axis; COVID-19; national security; export diversification.

For citation: Malevich Y. I., Yarmoshuk K. I. (2021). Izmeneniye strategii bezopasnosti Avstralii v Aziatsko-Tikhookeanskom regione [Change in Australia's security strategy in the Asian-Pacific region]. In: Actual Problems of International Relations and Global Development: collection of scientific papers. Minsk, vol. 9, p. 242-262. https://doi.org/10.33581/2311-9470-2021-9-242-262

\section{References}

1. Huong Le Thu. The COVID-19 Pandemic and Geopolitics in Southeast Asia [Electronic resource] // Australian Strategic Policy Institute. URL: https://www.aspi.org.au/opinion/covid-19pandemic-and-geopolitics-southeast-asia. (accessed: 22.05.2021).

2. Lowther A. The Asia-Pacific Century: Challenges and Opportunities // Air Force Research Institute [Electronic resource]. Alabama, 2013. URL: https://media.defense.gov/2017/Apr/07/ 2001728463/-1/-1/0/B_0132_LOWTHER_ASIA_PACIFIC1.PDF. (accessed: 04.05.2021).

3. Beley S. (2014) Faktor Kitaya v politike Avstralii v Aziatsko-Tihookeanskom regione [The China Factor in Australia's Asia-Pacific Policy] In: Journal of International Law and International Relations, 1. p. 33-37. (In Russ) 
4. Xiuzhong Xu V. Why Australia must not bow to China but seek wider trade options // Australian Strategic Policy Institute. [Electron-ic resource] URL: https://www.aspi.org.au/opinion/whyaustralia-must-not-bow-china-seek-wider-trade-options (accessed: 23.04.2021).

5. Jennings P. National security strategy can help us build key alliances to counter China // Australian Strategic Policy Institute. [Electronic resource] URL: https://www.aspi.org.au/opinion/ national-security-strategy-can-help-us-build-key-alliances-counter-china (accessed: 23.04.2021).

6. Jennings P. We need to reduce our dependence on China, and have the courage to call it out when required [Electronic resource] // Australian Strategic Policy Institute. URL: https://www.aspi. org.au/opinion/we-need-reduce-our-dependence-china-and-have-courage-call-it-out-when-required (accessed: 25.03.2021).

7. Khalil, P. The future of Australian foreign policy: beyond the major powers, towards a 'fulcrum' of middle powers // After Covid-19: Voices from federal parliament (Vol. 3). [Electronic resource]. URL: https://s3-ap-southeast-2.amazonaws.com/ad-aspi/2020-12/After\%20Covid-19\%20 Volume\%203_1.pdf?YAvLkXatwCsGNLpd82TXp.B9SGqkci3n (accessed: 15.04.2021).

8. Bachhawat A., Cave D. Critical technologies and the Indo-Pacific // Australian Strategic Policy Institute. [Electronic resource] URL: https://s3-ap-southeast-2.amazonaws.com/ad-aspi/202010/Critical\%20technologies_0.pdf?XWYJ1CHFPRHowYQcgeYRPD0LvmEEEGD7- (accessed: 15.04.2021).

9. Hull, G. Too Many Eggs in the Dragon's Basket? Part Two: Diversifying Australia's Export Base // Future Directions International. [Electronic resource]. URL: https://www.futuredirections. org.au/publication/too-many-eggs-in-the-dragons-basket-part-two-diversifying-australias-exportbase/ (accessed: 15.04.2021).

10. Wilson J. Trade Diversification is Essential for Australia's Recovery // Australian Institute of International Affairs. [Electronic resource] URL: https://www.internationalaffairs.org.au/ australianoutlook/trade-diversification-essential-for-australias-recovery (accessed: 15.04.2021).

11. Morrison K. Australia urged to diversify exports away from China // Argus Media Group. [Electronic resource] URL: https://www.argusmedia.com/en/news/2197091-australia-urged-todiversify-exports-away-from-china (accessed: 15.04.2021).

12. Dipanjan R. India-Australia trade \& investment ties to get major boost with Australia India Business Exchange launch // The Economic Times. [Electronic resource] URL: https://economictimes.indiatimes.com/news/international/world-news/india-australia-trade-investme nt-ties-to-get-major-boost-with-australia-india-business-exchange-launch/articleshow/81943822.

cms?utm_source=contentofinterest\&utm_medium=text\&utm_campaign=cppst (accessed: 15.08.21) 13. Jha Bhaskar N. Australia and India Economic Relations: The Stars Have Aligned // The Diplomat. [Electronic resource] URL: https://thediplomat.com/2020/12/australia-and-india-economicrelations-the-stars-have-aligned/ (accessed: 15.08.2021).

14. India-Australia trade agreement gathering momentum under Morrison: Report // bilaterals.org [Electronic resource]. 2021. URL: https://www.bilaterals.org/?india-australia-trade-agreement\&lang =en (accessed: 26.08.2021).

15. India - our next free trade agreement? // Business Australia [Electronic resource]. 2020. URL: https://www.businessaustralia.com/how-we-help/grow-your-business/preparing-to-export/india-ournext-free-trade-agreement (accessed: 24.08.2021).

Received: 30.09 .2021 .

About authors: Malevich Yulianna Igorevna - Doctor of Political Sciences, Professor, Professor of the Department of International Relations of the Belarusian State University; e-mail: myjill352@gmail.com.

Yarmoshuk Karina Igorevna - post-graduate student of the Department of International Relations, BSU; e-mail: karinayarmoshuk@gmail.com. 